\title{
Taxonomy of Corynebacterium Plant Pathogens, Including a New Pathogen of Wheat, Based on Polyacrylamide Gel Electrophoresis of Cellular Proteins $\dagger$
}

\author{
RANDALL R. CARLSON AND ANNE K. VIDAVER \\ Department of Plant Pathology, University of Nebraska, Lincoln, Nebraska 68583-0722
}

\begin{abstract}
The known extant plant pathogenic Corynebacterium species were analyzed by polyacrylamide gel electrophoresis of their cellular proteins. The patterns of the protein bands of 13 species and a new corynebacterial wheat pathogen showed seven distinct groups. Five of these groups consisted of only one species each, one group contained four species, and the last group contained the new wheat pathogen and the remaining four species. The pathogens that could not be distinguished by the polyacrylamide gel analysis differed in phenotypic characteristics, including pathogenic specificity. Thus, for these bacteria we propose recognition of the following taxa: Corynebacterium fascians (Tilford) Dowson, Corynebacterium ilicis (Mandel et al.), Corynebacterium tritici (ex Hutchinson) nom. rev., Corynebacterium iranicum (ex Scharif) nom. rev., Corynebacterium rathayi (Smith) Dowson, Corynebacterium flaccumfaciens subsp. flaccumfaciens (Hedges) Dowson, Corynebacterium flaccumfaciens subsp. poinsettiae (Starr and Pirone) comb. nov., Corynebacterium flaccumfaciens subsp. betae (Keyworth et al.) comb. nov., Corynebacterium flaccumfaciens subsp. oortii (Saaltink and Maas Geesteranus) comb. nov., Corynebacterium michiganense subsp. michiganense (Smith) Jensen, Corynebacterium michiganense subsp. nebraskense (Schuster et al.) comb. nov., Corynebacterium michiganense subsp. insidiosum (McCulloch) comb. nov., Corynebacterium michiganense subsp. sepedonicum (Spieckermann and Kotthoff), comb. nov., and Corynebacterium michiganense subsp. tessellarius subsp. nov., the type strain of which is strain 78181 (= ATCC $33566=$ PDDCC 7221).
\end{abstract}

An orange-pigmented coryneform bacterium was isolated from diseased wheat plants in 1976 and was subsequently identified as the causal agent of bacterial mosaic of wheat (5a). Studies were undertaken to determine the taxonomic relationship of this organism to other phytopathogenic corynebacteria, particularly the corn pathogen Corynebacterium nebraskense (Schuster et al. 1973) emend. Vidaver and Mandel 1974 (Approved Lists, 1980), since both of these pathogens are associated with plant diseases discovered in Nebraska. Preliminary results of this research have been presented elsewhere (Carlson and Vidaver, Phytopathology 69:1023, 1979; Carlson and Vidaver, Phytopathology 71:207, 1981).

The genus Corynebacterium contains bacteria with similar morphologies and a wide range of biochemical properties. Although attempts have been made to split the genus into homogeneous groups $(3,6,11,12,22,23,33,48,57)$, no proposal has been generally accepted. In this

$†$ Paper 6591 in the journal series of the Nebraska Agricultural Experiment Station. study, only the relationships among the phytopathogens traditionally included in the genus Corynebacterium were examined.

Kersters and De Ley (26) elegantly differentiated several gram-negative phytopathogenic bacteria by means of polyacrylamide tube gels; the results of these authors suggested that examination of phytopathogenic gram-positive bacteria by similar techniques might be useful and productive. In contrast to conventional tests, several gene products from more than one bacterium can be compared simultaneously in a slab gel. The only previous electrophoretic studies of proteins from phytopathogenic corynebacteria showed that "Corynebacterium tritici" (Hutchinson 1917) Burkholder 1948 and Corynebacterium fascians (Tilford 1936) Dowson 1942 (Approved Lists, 1980) differed from each other and from Corynebacterium betae Keyworth et al. 1956 (Approved Lists, 1980), Corynebacterium poinsettiae (Starr and Pirone 1942) Burkholder 1948 (Approved Lists, 1980), and Corynebacterium flaccumfaciens (Hedges 1922) Dowson 1942 (Approved Lists, 1980) with respect to the patterns of esterase, catalase, and 
peroxidase activities detected in starch gels (37) (names in quotation marks have no standing in bacterial nomenclature because they were not included on the Approved Lists of Bacterial Names [44] and have not been validly published since 1 January 1980). Polyacrylamide gel electrophoresis of 39 strains of Corynebacterium diphtheriae (Kruse 1886) Lehmann and Neumann 1896 (Approved Lists, 1980) showed differences among biovars, although extraction was poor and few distinct bands could be detected either by visual inspection or densitometer tracings (31).

The relationships among the phytopathogenic corynebacteria were assessed by gradient polyacrylamide gel electrophoresis (PAGE) of cellular proteins. A rationale for modifying the current classification of Corynebacterium plant pathogens is presented below, along with data supporting the classification of the bacterial mosaic pathogen as a subspecies of Corynebacterium michiganense (Smith 1910) Jensen 1934 (Approved Lists, 1980).

\section{MATERIALS AND METHODS}

Bacterial strains. A total of 80 isolates of the bacterial mosaic pathogen were obtained from diseased winter wheat cultivars; the isolation methods used are described elsewhere (5a). The specific strains of the bacterial mosaic pathogen (selected because of their differing bacteriocin production characteristics) and the other bacteria studied are listed in Table 1.

Media. Stock cultures were maintained both at $4^{\circ} \mathrm{C}$ on nutrient broth yeast extract medium (NBY medium) (55) and in the freeze-dried condition. The following media were used to determine growth characteristics: NBY medium (55); modified Burkholder agar (35); tetrazolium chloride medium (25), as modified by Vidaver and Mandel (56); and C. nebraskense selective medium (CNS medium) (16). Unless otherwise stated, experiments were performed at $25 \pm 3^{\circ} \mathrm{C}$.

Preparation of protein samples for PAGE. Cells were grown to early stationary phase (absorbance at 640 $\mathrm{nm}$, ca. $1.0 \mathrm{U}$, as determined with a Spectronic 20 colorimeter) in 10 to $30 \mathrm{ml}$ of NBY broth and were then washed three times by centrifugation in $0.2 \mathrm{M}$ sodium phosphate buffer $(\mathrm{pH} \mathrm{6.8)}$. The growth medium, cell growth stage at harvest, and protein extraction procedure were standardized to reduce the variation in the gel patterns. The final pellet was suspended in $2.0 \mathrm{ml}$ of the $\mathrm{NaPO}_{4}$ buffer. An equal volume of lysozyme solution $[1 \mathrm{mg} / \mathrm{ml}$ in $0.05 \mathrm{M}$ tris(hydroxymethyl)aminomethane- $0.02 \mathrm{M}$ ethylenediaminetetraacetate buffer, $\mathrm{pH} 8.0$ ] was added, and the mixture was incubated for $15 \mathrm{~min}$ at $37^{\circ} \mathrm{C}$. Sodium lauryl sulfate $(10 \%, \mathrm{wt} / \mathrm{vol})$ was added to a final concentration of $5 \%$. This treatment lysed most strains; if lysis was not apparent by increased viscosity and decreased turbidity, the cells were frozen $\left(-20^{\circ} \mathrm{C}\right)$ and thawed three times. Cellular proteins were extracted from the disintegrated cells essentially as described by Van Etten et al. (54). An equal volume of water-saturated phenol
TABLE 1. Bacterial strains examined by PAGE

\begin{tabular}{|c|c|}
\hline Organism & Strains $^{a}$ \\
\hline \multirow[t]{8}{*}{ C. michiganense } & $14-4$ \\
\hline & $13-3$ \\
\hline & $15-6$ \\
\hline & 1379 \\
\hline & 3D21 \\
\hline & $829 \mathrm{~S}$ \\
\hline & $15-2$ \\
\hline & $156-2$ \\
\hline \multirow[t]{8}{*}{ C. nebraskense } & CN74-1 \\
\hline & CN78-1 \\
\hline & CN48-1 \\
\hline & CN76-1 \\
\hline & 298 \\
\hline & 173 \\
\hline & N7A \\
\hline & CN18-6 \\
\hline \multirow[t]{4}{*}{ C. insidiosum } & 30 \\
\hline & 239 \\
\hline & MIB \\
\hline & $\mathrm{P} 2$ \\
\hline \multirow[t]{2}{*}{ C. sepedonicum } & CSca \\
\hline & $\mathrm{CSmt}$ \\
\hline \multirow[t]{3}{*}{ C. flaccumfaciens } & ATCC 6887 \\
\hline & $\mathrm{Ne} 21$ \\
\hline & CV7 \\
\hline \multirow[t]{2}{*}{ C. poinsettiae } & ICPB CP1 \\
\hline & ICPB CP13 \\
\hline \multirow[t]{2}{*}{$C$. betae } & ICPB CB101 \\
\hline & ICPB CB102A \\
\hline C. oortii & ICPB CO101 \\
\hline \multirow[t]{3}{*}{ C. ilicis } & PDDCC 2607 \\
\hline & PDDCC 2608 \\
\hline & PDDCC 2609 \\
\hline \multirow[t]{3}{*}{ C. fascians } & $6 \mathrm{D} 21$ \\
\hline & CF79-1 \\
\hline & ICPB CF107 \\
\hline \multirow[t]{2}{*}{ C. rathayi } & ICPB CR1 \\
\hline & ICPB CR101 \\
\hline \multirow[t]{3}{*}{ "C. tritici" } & NCPPB 1857 \\
\hline & ICPB CT101 \\
\hline & ICPB CT102 \\
\hline "C. iranicum" & NCPPB 2253 \\
\hline C. bovis & $\begin{array}{l}\text { ATCC } 7715 \\
1\end{array}$ \\
\hline M. luteus & ATCC 4698 \\
\hline \multirow[t]{6}{*}{ Bacterial mosaic pathogen } & 78141 \\
\hline & 78151 \\
\hline & $78181(=$ ATCC 33566) \\
\hline & 78221 \\
\hline & 78222 \\
\hline & 78271 \\
\hline
\end{tabular}

a Strains were obtained from the American Type Culture Collection (ATCC), International Collection of Phytopathogenic Bacteria (ICPB), Plant Disease Division Culture Collection (PDDCC), and National Collection of Plant Pathogenic Bacteria (NCPPB). If not otherwise identified, strains were obtained from other investigators or are Nebraska isolates.

( $85 \mathrm{~g}$ of phenol, $16 \mathrm{ml}$ of water, $1 \mathrm{ml}$ of $1 \mathrm{~N} \mathrm{NaOH}$ ) was mixed with the lysate by blending with a Vortex mixer, the suspension was centrifuged at low speed, and the 
phenol layer (lower layer) was removed without disturbing the water phase (upper layer) or the interface. The phenol-soluble proteins were precipitated from the phenol phase by adding 5 volumes of methanol containing $0.1 \mathrm{M}$ ammonium acetate, mixing well, and then incubating the preparation at $-20^{\circ} \mathrm{C}$ for at least 2 h. The precipitate was collected by low-speed centrifugation and was washed once with methanol $(10 \mathrm{ml})$; the final pellet was dried under a vacuum. The cellular proteins were dissolved in $100 \mu \mathrm{l}$ of sample buffer [ 2.5 $\mathrm{g}$ of Ficoll (Pharmacia), $1 \mathrm{ml}$ of $0.1 \%$ crystal violet, 5 $\mathrm{ml}$ of $10 \%$ (wt/vol) sodium lauryl sulfate, $0.5 \mathrm{ml}$ of $3 \mathrm{M}$ tris(hydroxymethyl)aminomethane $(\mathrm{pH} \mathrm{8.8)}, 16 \mathrm{ml}$ of water] by boiling for $1 \mathrm{~min}$ or more. Dithioerythritol $(77 \mathrm{mg} / \mathrm{ml}$ ) was added at 1 part per 100 just before boiling. Reference proteins were dissolved in sample buffer and electrophoresed in the outside lanes of the gel; $2.5 \mu \mathrm{g}$ of a reference protein was detectable when the preparation was stained. The residual lysozyme in each sample served as an internal marker.

PAGE. The gradient slab gels (vertical) used were supported in a Studier apparatus (51). The gels were made as described by Ames (1), and the buffer system of Laemmli (29) was used. The separating gel (lower gel) was composed of a linear 8 to $20 \%$ polyacrylamide gradient, and the stacking gel (upper gel) contained $4.2 \%$ polyacrylamide (53). Samples ( 5 to $25 \mu \mathrm{l}$; optimum quantity determined empirically) were electrophoresed at $60 \mathrm{~V}(4 \mathrm{~V} / \mathrm{cm})$ until the crystal violet in the sample buffer eluted from the gel (about $20 \mathrm{~h}$ ). The gels were strained for $1 \mathrm{~h}(\mathbf{0 . 5} \mathrm{g}$ of Coomassie brilliant blue $\mathrm{R}, 455 \mathrm{ml}$ of methanol, $455 \mathrm{ml}$ of water, $90 \mathrm{ml}$ of glacial acetic acid) in a container placed on a slow-moving platform in a $50^{\circ} \mathrm{C}$ water bath shaker. The gels then were destained against several changes of destaining solution $(35 \%$ [vol/vol] methanol and $10 \%[\mathrm{vol} / \mathrm{vol}]$ glacial acetic acid in water) at $50^{\circ} \mathrm{C}$ in a water bath shaker. The destained gels were photographed with Polaroid type 665 film through an orange filter. The gels could be stored for reference at room temperature in destaining solution.

$\mathrm{G}+\mathbf{C}$ content of the DNA. The guanine-plus-cytosine $(G+C)$ content of the deoxyribonucleic acid (DNA) was determined as previously described $(42,56)$.

Tetrazolium salt susceptibility. Growth on tetrazolium chloride medium with any of several tetrazolium derivatives substituted for triphenyltetrazolium chloride was scored as positive if single colonies grew on a streak plate within 2 weeks. The following derivatives were tested: iodonitrotetrazolium, $o$-tolyl tetrazolium, $m$-Nitro Blue Tetrazolium, neotetrazolium, tetrazolium blue, and tetrazolium violet. Ethanol was sometimes added to stock solutions to solubilize the derivatives.

Plasmid DNA detection. Bacterial DNA was extracted, purified, and assayed for the presence of plasmids as described previously (18).

Bacteriocin production and assay. The conditions used for the production and assay of bacteriocins are described elsewhere (17).

Plant inoculation methods. Winter wheat (Triticum aestivum L. 'Centurk'), maize (Zea mays L. 'Golden Cross Bantam'), and tomato (Lycopersicon esculentum Mill. 'Mocross Surprise') were inoculated by the partial vacuum technique (15) with strains of the bacterial mosaic pathogen, $C$. nebraskense, and $C$. michiganense in all host-pathogen combinations to

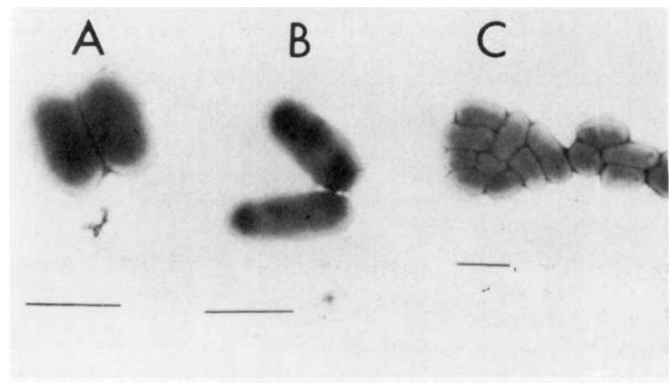

FIG. 1. Electron micrographs of the bacterial mosaic pathogen. (A) Strain 78181. (B) Strain 78222. (C) Strain 78141. Bars $=1 \mu \mathrm{m}$.

determine host specificity ( $C$. michiganense and $C$. nebraskense are pathogens of tomato and corn, respectively). The pathogen concentrations in the inocula were adjusted to $10^{6}$ colony-forming units per $\mathrm{ml}$.

\section{RESULTS}

Morphology and growth characteristics of the bacterial mosaic pathogen. Cells of the bacterial mosaic pathogen were gram-positive, nonmotile (between 20 and $28^{\circ} \mathrm{C}$ ) rods with a pleomorphism characteristic of coryneform bacteria. Cells measured approximately 0.5 by $1.5 \mu \mathrm{m}$ (Fig. 1). Growth on NBY medium, modified Burkholder agar, and CNS medium was slow, with colonies becoming visible in 2 to 3 days. Full colony development required 5 to 7 days. Colonies were circular (diameter, 2 to $4 \mathrm{~mm}$ ), convex, glistening, and butyrous and had entire margins. Strains grew at $10^{\circ} \mathrm{C}$ but not at $37^{\circ} \mathrm{C}$. The temperature for optimal growth was between 24 and $28^{\circ} \mathrm{C}$. The intensity of pigmentation varied with the medium and the age of the culture, but all strains produced an apricot orange pigment. The colony colors on tetrazolium chloride medium (see below) varied from pale blue to red, depending on the derivative of tetrazolium included in the agar. $C$. michiganense, $C$. nebraskense, Corynebacterium insidiosum (McCulloch 1925) Jensen 1934 (Approved Lists, 1980), and Corynebacterium sepedonicum (Spieckermann and Kotthoff 1914) Skaptason and Burkholder 1942 (Approved Lists, 1980) could be differentiated from each other by their reactions to two tetrozolium salts, triphenyltetrazolium chloride and iodonitrotetrazolium; $C$. michiganense and the bacterial mosaic pathogen gave identical reactions (Table 2 ). The inability of $C$. sepedonicum to grow on iodonitrotetrazolium and triphenyltetrazolium chloride was not consistent with previously reported results (56), possibly because of strain variation. $C$. nebraskense was unable to grow on triphenyltetrazolium chloride, a characteristic that distinguished this species from both $C$. michiganense and the bacterial 
TABLE 2. Some differentiating characters of $C$. michiganense, $C$. nebraskense, $C$. insidiosum, $C$. sepedonicum, and the bacterial mosaic pathogen

\begin{tabular}{|c|c|c|c|c|c|c|c|}
\hline \multirow[b]{2}{*}{ Organism } & \multicolumn{3}{|c|}{ Growth on: } & \multirow[b]{2}{*}{ Pigment $^{d}$} & \multirow{2}{*}{$\begin{array}{c}G+C \\
\text { content } \\
(\operatorname{mol} \%)^{t^{\prime}}\end{array}$} & \multirow{2}{*}{ Host Specificity ${ }^{f}$} & \multirow{2}{*}{ Colony type ${ }^{f}$} \\
\hline & $\begin{array}{c}\mathrm{CNS} \\
\text { medium }^{a}\end{array}$ & $\begin{array}{l}\text { INT } \\
\text { agar }^{b}\end{array}$ & $\begin{array}{l}\text { TTC } \\
\text { agar }^{r}\end{array}$ & & & & \\
\hline C. sepedonicum & - & -- & - & White & 72 & Potato & Fluidal \\
\hline C. insidiosum & - & $\rightarrow$ & + & Yellow & 73 & Alfalfa & Fluidal \\
\hline C. nebraskense & + & + & - & Orange & 73.5 & Corn & Domed, mucoid \\
\hline C. michiganense & + & + & + & Yellow & 73 & Tomato, pepper & Fluidal \\
\hline Bacterial mosaic pathogen & + & + & + & Orange & 74 & Wheat & Domed, mucoid \\
\hline
\end{tabular}

"See reference 16 .

$b$ INT agar, Agar containing $10 \mu \mathrm{g}$ of iodonitrotetrazolium per $\mathrm{ml}$.

c TTC agar, Agar containing $50 \mu \mathrm{g}$ of triphenyltetrazolium chloride per $\mathrm{ml}$.

${ }^{d}$ Colony pigmentation on NBY agar.

' Data from Vidaver and Mandel (56), except for the data for the bacterial mosaic pathogen.

${ }^{f}$ See text for references.

mosaic pathogen. Neither C. sepedonicum nor $C$. insidiosum grew on selective medium CNS, in contrast to C. michiganense, $C$. nebraskense, and the bacterial mosaic pathogen. Table 3 lists additional comparative characters for the Corynebacterium plant pathogens.

$\mathbf{G}+\mathbf{C}$ contents of DNAs. The $\mathrm{G}+\mathrm{C}$ contents of DNAs were as follows: strain $77113,73.5 \mathrm{~mol} \%$; strain $7661,74.0 \mathrm{~mol} \%$; and strain $77143,74.5$ mol\% $\left(1.732\right.$ to $\left.1.733 \mathrm{~g} / \mathrm{cm}^{3}\right)$. Comparative $\mathrm{G}+\mathrm{C}$ values for $C$. michiganense, $C$. nebraskense, $C$. insidiosum, and $C$. sepedonicum are listed in Table 2.

PAGE of cellular proteins. The patterns of the protein bands clearly differentiated some of the species but not others. The use of a gradient gel enabled resolution of proteins ranging in molecular weight from 10,000 to 120,000 in a gel $15 \mathrm{~cm}$ long. For any given strain, the patterns were reproducible throughout analyses of the same sample in successive gels; independent extractions of the same strain also gave indistinguishable patterns. The strains of each species gave similar overall patterns, but the patterns could differ in specific bands. All of the strains listed in Table 1 were analyzed by this method. Different strains of $C$. nebraskense (Fig. 2) and C. michiganense (Fig. 3) showed nearly identical protein patterns. The variation in the protein patterns was slightly greater among the strains of $C$. michiganense than among the strains of $C$.nebraskense. The protein bands of the bacterial mosaic pathogen (Fig. 4, lane F), C. michiganense (lane D), $C$. nebraskense (lane E), $C$. insidiosum (lane C), and C. sepedonicum (lane B) were very similar. Likewise, the patterns for the nomenspecies $C$. flaccumfaciens (Fig. 5, lane C), $C$. betae (lane D), $C$. poinsettiae (lane B), and Corynebacterium oortii Saaltink and Maas Geesteranus 1969 (Approved Lists, 1980) (lane E) were very similar. In both Fig. 4 and 5, the variation among the species of each group was minor, little more than the variation encountered among strains of a single species (Fig. 2 and 3). The four Corynebacterium pathogens of wheat, "C. tritici" (Fig. 6, lane E), "Corynebacterium iranicum" Scharif 1961 (lane D), Corynebacterium rathayi (Smith 1913) Dowson 1942 (Approved Lists, 1980) (lane F), and the bacterial mosaic pathogen (lane $\mathrm{C}$ ), were distinctly different. The mammal-associated species Corynebacterium bovis Bergey et al. 1923 (Approved Lists, 1980) (Fig. 7, lane I) and the gram-positive coccus Micrococcus luteus (Schroeter 1872) Cohn 1872 (Approved Lists, 1980) (lane J) had protein patterns that were clearly different from those of the phytopathogens (lanes B through $\mathrm{H})$.

Bacteriocins of the bacterial mosaic pathogen. Most strains of the bacterial mosaic pathogen produced a single bacteriocin, but a few strains produced two bacteriocins simultaneously and some strains produced none at all (Table 4). Four distinct bacteriocins were detected; three of these were unique to the bacterial mosaic pathogen (Fig. 8), as shown by a second set of indicator strains (17). The fourth bacteriocin could not be differentiated from the bacteriocin produced by $C$. nebraskense CN74-1 (Fig. 8). The type of bacteriocin produced by the bacterial mosaic pathogen could not be correlated with geographic source, wheat cultivar, or year of isolation (data not shown); e.g., all four bacteriocins were produced by strains isolated from adjacent plots in a cultivar field trial. The production of bacteriocin was used to type the strains, as this was a more reliable character than susceptibility to bacteriocins.

Disease reactions. Greenhouse-grown wheat inoculated with strains of the bacterial mosaic pathogen readily developed the scattered yellow lesions characteristic of the disease after 3 to 5 


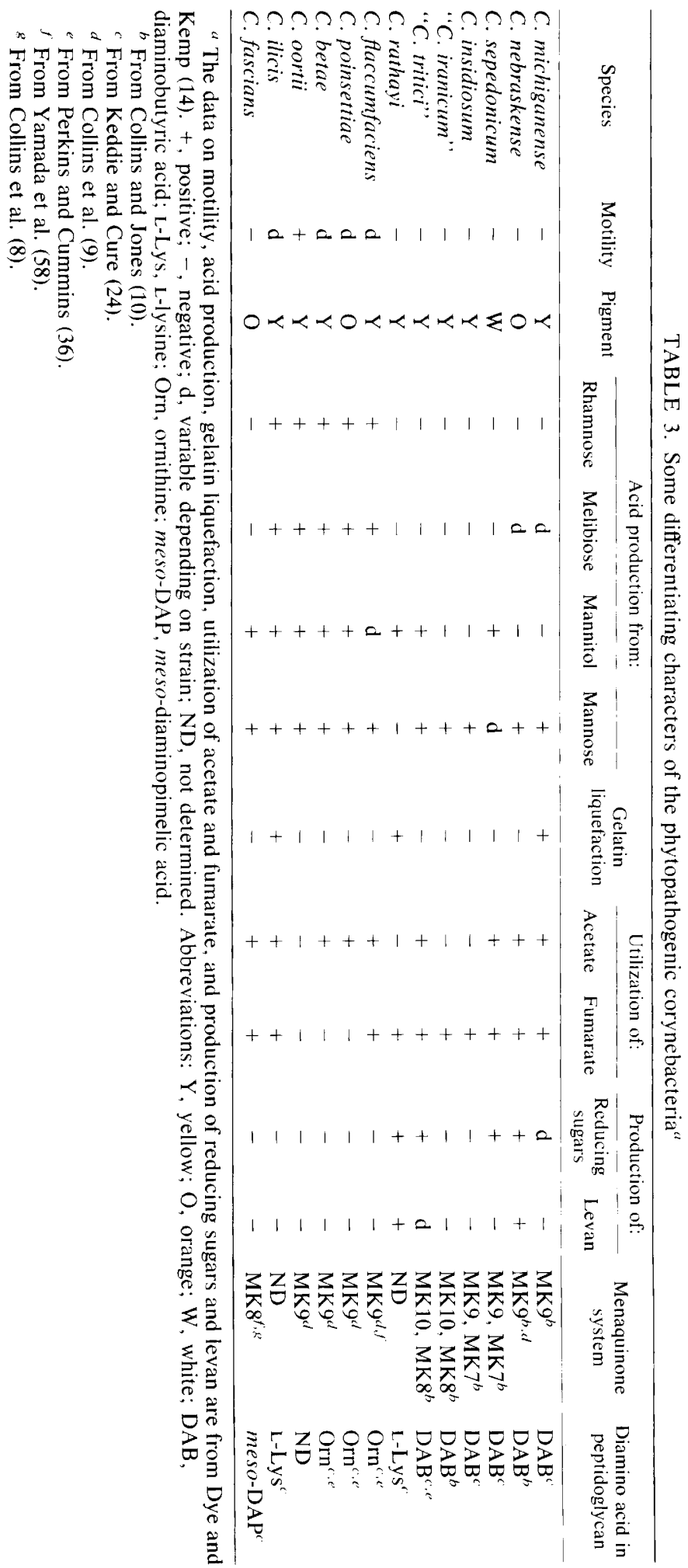




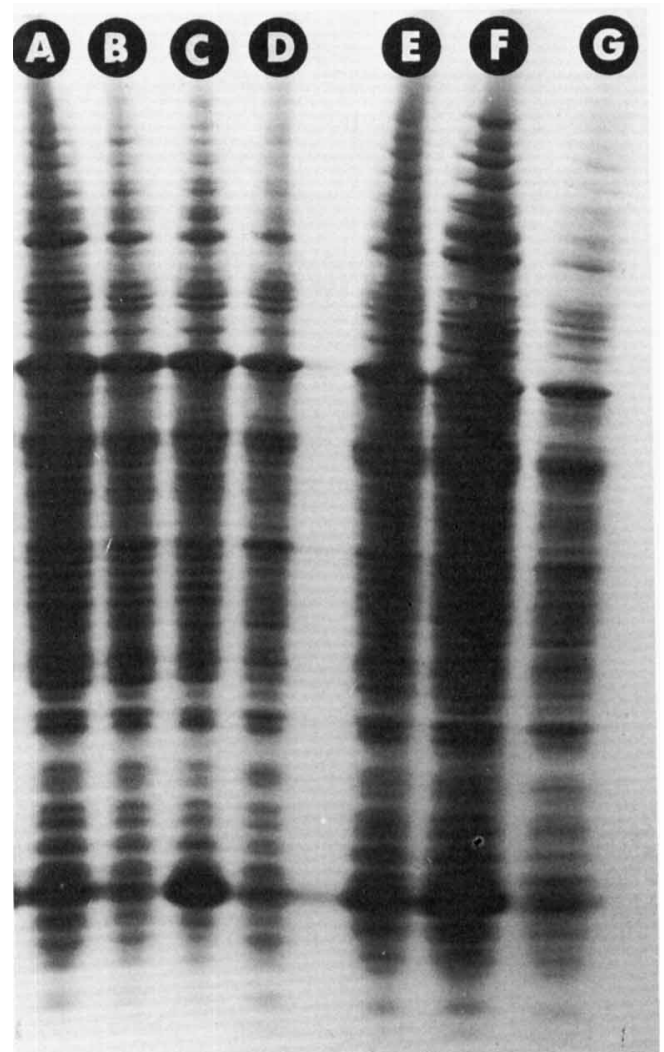

FIG. 2. Protein patterns of $C$. nebraskense in a polyacrylamide slab gel. Samples were electrophoresed from top to bottom. Lane A, Strain CN76-1; lane $\mathrm{B}$, strain CN74-1; lane $\mathrm{C}$, strain CN74-1 (independent extraction); lane D, strain CN48-1; lane E, strain 298; lane $F$, strain N7A; lane G, strain 173 .

days of incubation. The relative populations of the bacterial mosaic pathogen, $C$. michiganense, and $C$. nebraskense in inoculated wheat, corn, and tomato plants showed that the highest population levels occurred in natural hosts, as shown elsewhere (5a). Neither $C$. michiganense nor $C$. nebraskense produced symptoms in wheat.

Plasmid analysis. Seven strains were examined for the presence of plasmids; of these, only strain 78151 contained detectable plasmid DNA. The plasmid was about 32 megadaltons long, as determined by a comparison with a 34-megadalton plasmid of $C$. nebraskense (18). Since plasmids are rare, they are unlikely to determine major properties of the bacterial mosaic pathogen.

\section{DISCUSSION}

The initial recognition of plant pathogens as distinct species of Corynebacterium was made on the presumption that pathogens of diverse

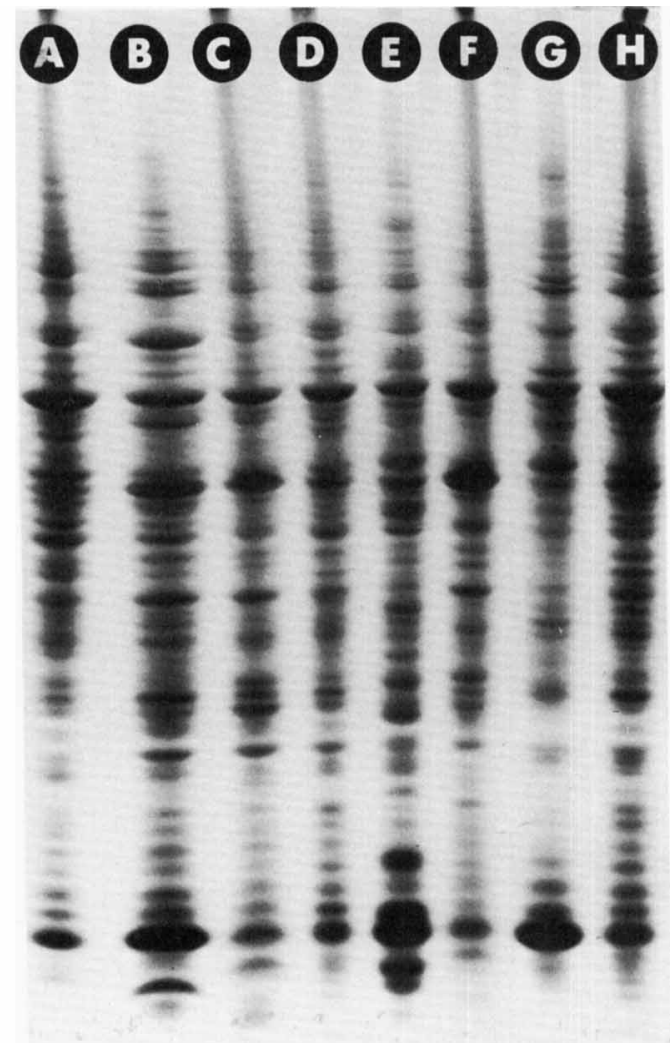

FIG. 3. Protein patterns of $C$. michiganense in a polyacrylamide slab gel. Samples were electrophoresed from top to bottom. Lane A, strain 156-2; lane B, strain 14-4; lane C, strain 3D21; lane D, strain 15-6; lane E, strain 15-2; lane F, strain $829 \mathrm{~S}$; lane $G$, strain 1379; lane $\mathrm{H}$, strain 13-3.

plant hosts would be quite different; recognition of the similarity of these pathogens was delayed due to the lack of appropriate comparative analyses of groups of pathogens. The current edition of Bergey's Manual of Determinative Bacteriology (4) lists 12 species of plant pathogens in the genus Corynebacterium. Dye and Kemp (14) have proposed that all of the corynebacterial phytopathogens should be assigned to four species (C. michiganense, C. flaccumfaciens, Corynebacterium ilicis, and C. fascians) on the basis of their numerical taxonomy study. With some notable exceptions, our study generally supports the taxonomic groupings of these authors. Thus, we propose revising the nomenclature of the phytopathogenic corynebacteria as discussed below.

The nomenspecies $C$. michiganense, $C$. nebraskense, $C$. insidiosum, and $C$. sepedonicum were nearly identical when they were analyzed by PAGE; on this basis, we concur with the proposal of Dye and Kemp (14) to combine these 


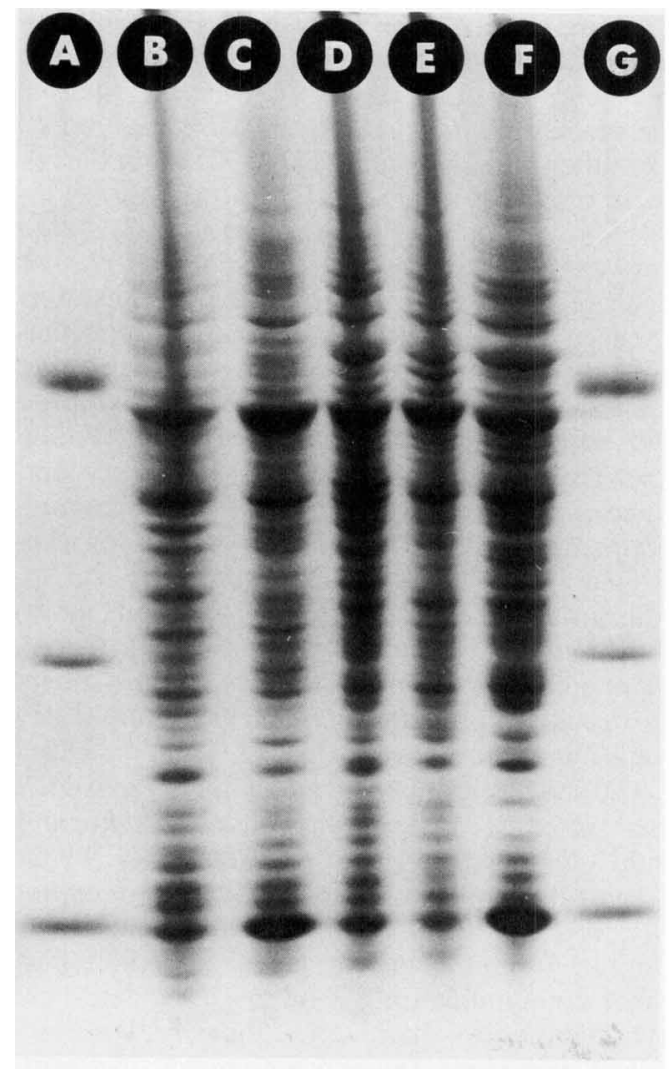

FIG. 4. Protein patterns of $C$. sepedonicum, $C$. insidiosum, $C$. michiganense, $C$. nebraskense, and the bacterial mosaic pathogen in a polyacrylamide slab gel. Samples were electrophoresed from top to bottom. Samples containing three standard proteins were electrophoresed in lanes A and G. These proteins were (from top to bottom) bovine serum albumin (molecular weight, 66,300), carbonic anhydrase B $(28,000)$, and lysozyme $(14,300)$. Each standard protein band contained approximately $2.5 \mu \mathrm{g}$ of protein. Lane B, $C$. sepedonicum strain 30 ; lane $C, C$. insidiosum strain $\mathrm{P} 2$; lane $\mathrm{D}, C$. michiganense strain 156-2; lane E, $C$. nebraskense strain CN74-1; lane $\mathrm{F}$, bacterial mosaic pathogen strain 78221 .

organisms into a single species. Dye and Kemp concluded that there are insufficient differences among these bacteria to justify recognition of them as distinct taxa at even the subspecies level; they argued for infrasubspecific status for these bacteria as pathovars of $C$. michiganense. The classification of these bacteria as pathovars would retain the traditional names of pathogens that cause specific and differentiable diseases. In its recommendations for infrasubspecific terms, the International Code of Nomenclature of Bacteria (30) defines pathovars as bacteria that differ in "pathogenic reactions in one or more hosts." Dye and Kemp (14) contend that patho-

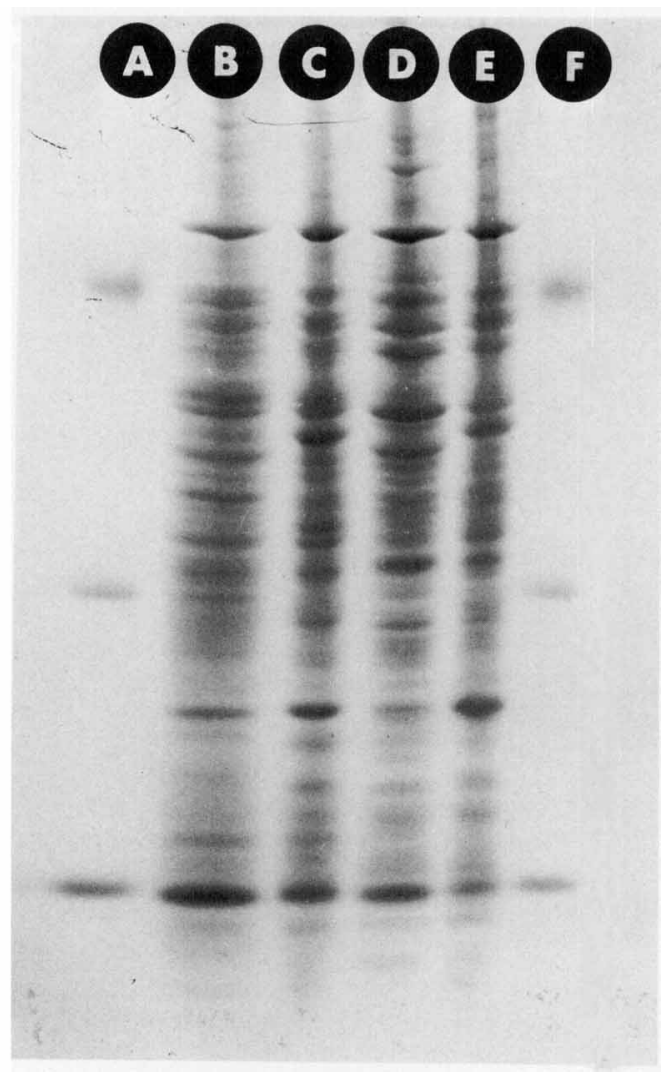

FIG. 5. Protein patterns of C. poinsettiae, C. flaccumufaciens, $C$. betae, and $C$. oortii in a polyacrylamide slab gel. Samples were electrophoresed from top to bottom. The standard proteins in lanes $\mathrm{A}$ and $\mathrm{F}$ were as described in the legend to Fig. 4. Lane B, $C$. poinsettiae strain $\mathrm{CP} 1$; lane $\mathrm{C}, \mathrm{C}$. flaccumfaciens strain $\mathrm{Ne} 21$; lane $\mathrm{D}, C$. betae strain CB102A; lane $\mathrm{E}$, C. oortii strain CO101.

vars can also differ in a limited number of biochemical and physiological properties. However, we believe that numerous differences among these bacteria require classification at the higher level of subspecies. We show that these taxa differ with respect to tetrazolium salt tolerances, colony morphology and pigmentation, and overall bacteriocin production. These bacteria also differ in their reactions to many biochemical tests (Tables 2 and 3 ), and $C$. insidiosum and $C$. sepedonicum differ from $C$. nebraskense and $C$. michiganense in their menaquinone systems (Table 3). All of these characters are independent of pathogenic specificity. The designation of these organisms as subspecies would retain the traditional names of these bacteria, would avoid the implication of the term pathovar that pathogenicity is an overriding taxonomic character, and would allow the rational identification of related saprophytes and aviru- 


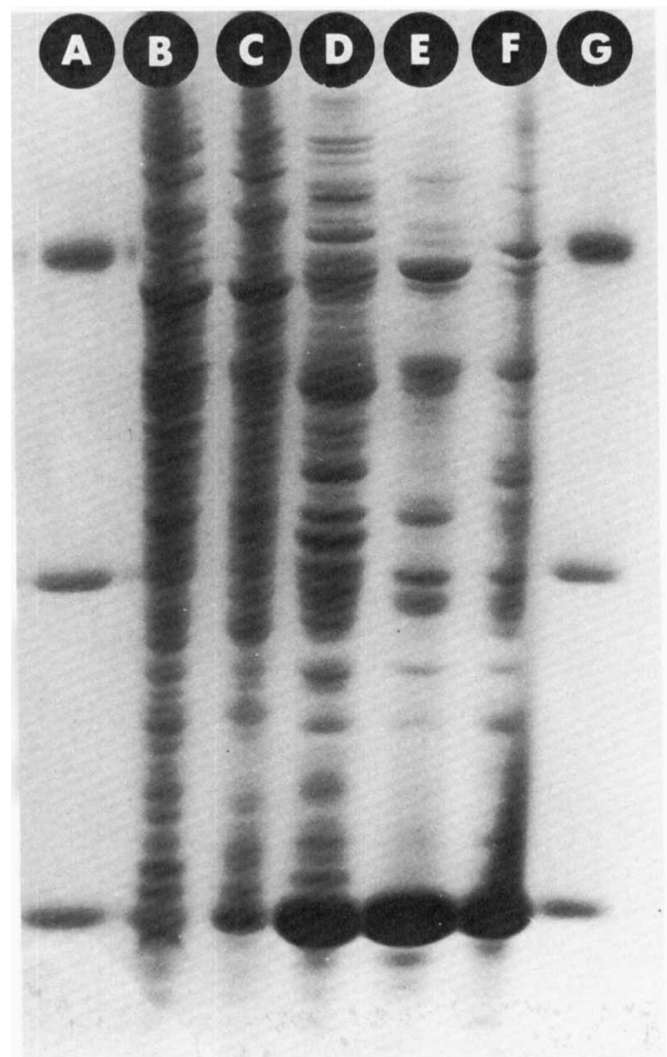

FIG. 6. Protein patterns of C. michiganense, bacterial mosaic pathogen, "C. iranicum," "C. tritici," and $C$. rathyai in a polyacrylamide slab gel. Samples were electrophoresed from top to bottom. The standard proteins in lanes $A$ and $G$ were as described in the legend to Fig. 4. Lane B, C. michiganense strain 1562; lane C, bacterial mosaic pathogen strain 78271; lane D, "C. iranicum" strain 2253; lane E, " $C$. tritici" strain CT102; lane F, C. rathayi strain CR101.

lent derivatives. For example, a strain isolated from a weed grass was indistinguishable from bacterial mosaic strains by PAGE but was not pathogenic to wheat or several other hosts (Carlson and Vidaver, unpublished data). This isolate could not be classified as a pathovar until a proper host was found; however, it could be classified as a subspecies based on laboratory tests. Therefore, we propose the following new combinations: $C$. michiganense subsp. michiganense (Smith 1910) Jensen 1934 (Approved Lists, 1980; Rule 4b [30]); C. michiganense subsp. insidiosum (McCulloch 1925) comb. nov.; $C$. michiganense subsp. nebraskense (Schuster et al. 1973) comb. nov.; and C. michiganense subsp. sepedonicum (Spieckermann and Kothoff 1914) comb. nov.

The pathogens $C$. flaccumfaciens, $C$. poinsettiae, $C$. betae, and C. oortii are nearly identical according to a PAGE analysis of their cellular proteins, thus supporting the proposal of Dye and Kemp (14) that they should be included in one species, $C$. flaccumfaciens. However, these taxa differ biochemically (Table 3 ) and in bacteriocin production (17). Furthermore, Starr et al. (49) showed that $C$. poinsettiae and $C$. betae were only $20 \%$ related to $C$. flaccumfaciens, as measured by DNA-DNA homology. These differences are independent of pathogenic specificity, and on this basis we believe that these bacteria should be considered subspecies rather than pathovars, as suggested by Dye and Kemp (14). Thus, we propose that these taxa be combined as follows: C. flaccumfaciens subsp. flaccumfaciens (Hedges 1922) Dowson 1942 (Approved Lists, 1980); C. flaccumfaciens subsp. poinsettiae (Starr and Pirone 1942) comb. nov.; C. flaccumfaciens subsp. betae (Keyworth et al. 1956) comb. nov.; and C. flaccumfaciens subsp. oortii (Saaltink and Maas Geesternaus 1969) comb. nov.

The species grouped into $C$. michiganense ( $C$. nebraskense, $C$. sepedonicum, $C$. insidiosum) and $C$. flaccumfaciens $(C$. poinsettiae, $C$. betae, $C$. oortii) were also grouped with $C$. michiganense or C. Alaccumfaciens by Döpfer et al. ( $\mathrm{H}$. Döpfer, E. Stackebrandt, and F. Fiedler, personal communication), who used nucleic acid hybridization to characterize their strains.

The pathogens causing gummosis of wheat, " $C$. tritici," " $C$. iranicum," and $C$. rathayi, differ from one another and from the other phytopathogens of the genus in their protein patterns on polyacrylamide gels (Fig. 6 and 7). Dye and Kemp (14) argued for the inclusion of these three species in $C$. michiganense, but for these organisms the differences shown by PAGE analyses are easily as great as the differences between $C$. flaccumfaciens and C. michiganense. These results contrast with the near identity of the protein patterns for the other species which Dye and Kemp assigned to C. michiganense (see above). Differences in menaquinone systems distinguish " $C$. iranicum" and " $C$. tritici" (Table 3), and the cell wall amino acid Llysine distinguishes $C$. rathayi (Table 3 ) from $C$. michiganense. Furthermore, " $C$. tritici" differs from $C$. sepedonicum in gross differential use of the pentose cycle (59). We believe that these differences are sufficient to justify species status for these bacteria; however, of the three, only $C$. rathayi was included on the Approved Lists (44). Therefore, we propose that the other two names be revived and used for the bacteria previously known by these appellations, as follows: Corynebacterium iranicum (ex Scharif 1961) nom. rev. and Corynebacterium tritici (ex Hutchinson 1917) nom. rev.

C. iranicum nom. rev. Gram-positive, nonmo- 


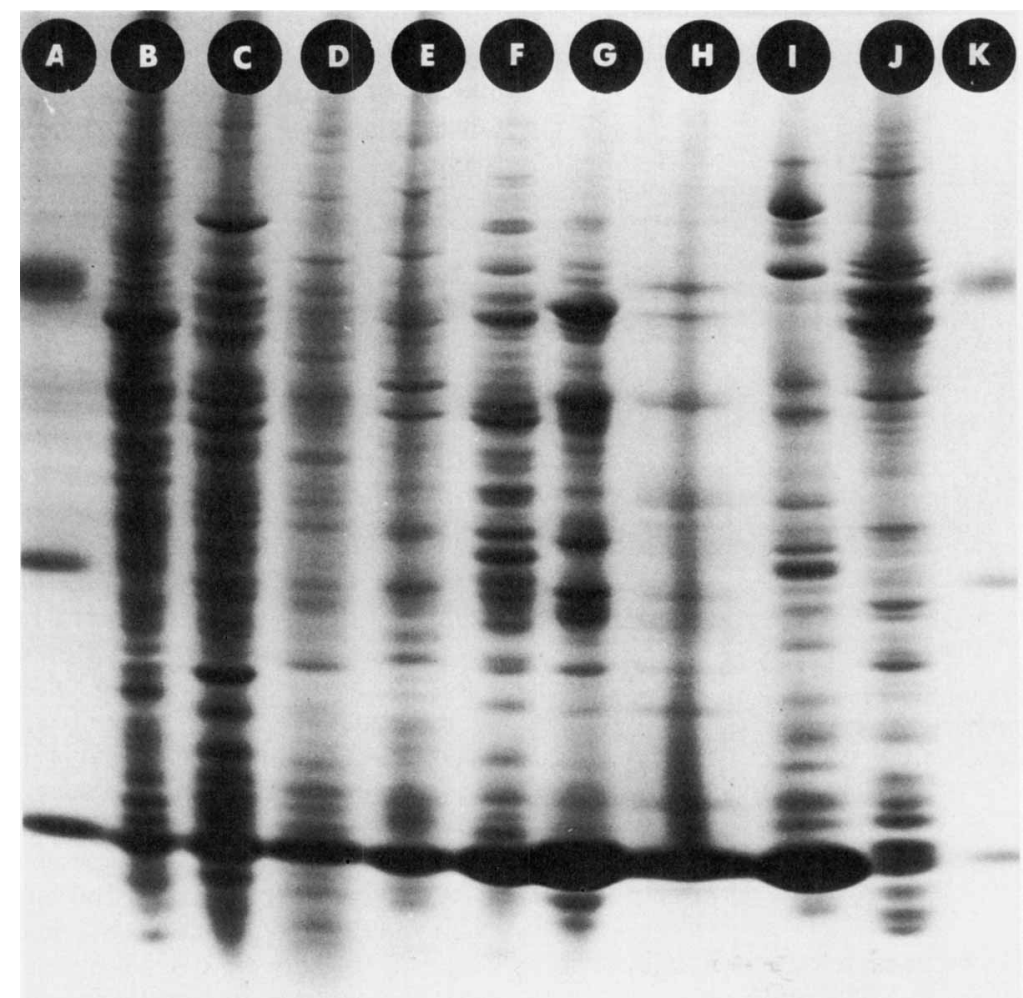

FIG. 7. Protein patterns of $C$. michiganense, C. flaccumfaciens, C. ilicis, C. fascians, " C. iranicum," " $C$. tritici," $C$. rathayi, $C$. bovis, and $M$. luteus in a polyacrylamide slab gel. Samples were electrophoresed from top to bottom. The standard proteins in lanes $\mathrm{A}$ and $\mathrm{K}$ were as described in the legend to Fig. 4. Lane B, $C$. michiganense strain 156-2: lane C, C. flaccumfaciens strain Ne21: lane D, $C$. ilicis strain 2607; lane E, $C$. fascians strain CF107; lane F, "C. iranicum" strain 2253; lane G, " $C$. tritici" strain CT102; lane H, $C$. rathayi strain CR101; lane I, C. bovis strain 7715; lane J, M. luteus strain 4698.

TABLE 4. Bacteriocin types of the bacterial mosaic pathogen

\begin{tabular}{|c|c|c|c|c|c|c|}
\hline \multirow{2}{*}{$\begin{array}{l}\text { Bacteriocin } \\
\text { type }\end{array}$} & \multirow{2}{*}{$\begin{array}{l}\text { Representative } \\
\text { strain }\end{array}$} & \multicolumn{4}{|c|}{$\begin{array}{l}\text { Diam of inhibition zones ( } \mathrm{mm} \text { ) with the following } \\
\text { indicator strains: }\end{array}$} & \multirow{2}{*}{$\begin{array}{l}\text { Frequency } \\
(\%)^{\prime \prime}\end{array}$} \\
\hline & & 7771 & 77212 & 77251 & 77143 & \\
\hline 1 & 78222 & $6-10$ & & & & 12.7 \\
\hline 2 & 78152 & & $8-12$ & & $8-12$ & 34.2 \\
\hline 3 & 78181 & & & $1-3$ & $1-3$ & 11.4 \\
\hline 4 & 78151 & $3-6$ & $3-6$ & $3-6$ & $3-6$ & 1.3 \\
\hline $1+3$ & 78221 & $6-10$ & & $6-10$ & $1-3$ & 1.3 \\
\hline $2+3$ & 78141 & & $8-12$ & $1-3$ & $8-12$ & 16.5 \\
\hline 0 & 78271 & & & & & 11.4 \\
\hline
\end{tabular}

${ }^{a}$ Based on 79 strains tested; an additional $11.4 \%$ could not be typed.

tile, pleomorphic rods, with a temperature maximum of $30^{\circ} \mathrm{C}$. Colonies are circular (diameter, 2 to $4 \mathrm{~mm}$ ), convex, and yellow pigmented on NBY medium. Produces acid from xylose, glucose, fructose, galactose, mannose, lactose, sucrose, maltose, trehalose, cellobiose, melezitose, and glycerol but not from rhamnose, ribose, melibiose, raffinose, adonitol, mannitol, sorbitol, dulcitol, inositol, salicin, $\alpha$-methyl glucoside, $\beta$-methyl glucoside, or esculin. Utilizes citrate, fumarate, malate, and succinate but not acetate or lactate. Does not hydrolyze starch and has a maximum $\mathrm{NaCl}$ tolerance of $2 \%$. Distinguished from other Corynebacterium spp. by the presence of diaminobutyric acid in its peptidoglycan, its characteristic menaquinones 


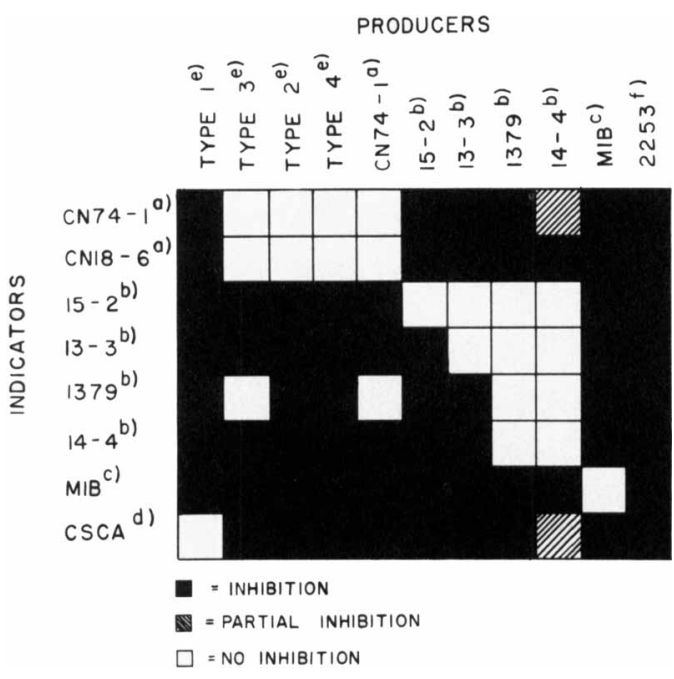

FIG. 8. Differentiation of the bacteriocins of phytopathogenic corynebacteria on NBY medium. The producers and indicators were strains of $C$. nebraskense (superscript a), C. michiganense (superscript b), $C$. insidiosum (superscript c), C. sepedonicum (superscript d), bacterial mosaic pathogen (superscript e), and "C. iranicum." (superscript $\mathrm{f}$ ).

(MK10 and MK8), and its distinct pattern of protein bands in polyacrylamide gels. Isolated from wheat (T. aestivum $\mathrm{L}$.) showing a gumming disease of the seedheads. The type strain is strain NCPPB 2253, the reference strain of Dye and Kemp (14). As the preceding description is based on a single strain, the type strain, the species description also serves as a description of the type strain.

C. tritici nom. rev. Gram-positive, nonmotile, pleomorphic rods, with a temperature maximum of $34^{\circ} \mathrm{C}$. Colonies are circular (diameter, 2 to 4 $\mathrm{mm}$ ), convex, and yellow pigmented on NBY medium. Produces acid from xylose, glucose, fructose, galactose, mannose, sucrose, maltose, trehalose, cellobiose, glycerol, and mannitol but not from rhamnose, ribose, lactose, melibiose, raffinose, melezitose, adonitol, sorbitol, dulcitol, inositol, salicin, $\alpha$-methyl glucoside, $\beta$ methyl glucoside, or esculin. Utilizes acetate, citrate, fumarate, and succinate but not formate, lactate, or propionate. Does not hydrolyze starch and has a maximum $\mathrm{NaCl}$ tolerance of 3 to $4 \%$. Distinguished from other Corynebacterium spp. by the presence of diaminobutyric acid in its peptidolyglycan, its characteristic menaquinones (MK10 and MK8), and its distinct pattern of protein bands in polyacrylamide gels. Isolated from wheat (T. aestivum L.) showing a gumming disease of the leaves, stems, and seedheads. The type strain is ATCC 11403 (= NCPPB 1857), the reference strain of Dye and Kemp (14). The preceding description is based on six strains (including the type strain) characterized by Dye and Kemp (14). As the tests for these six strains were uniform, the species description also serves as a description of the type strain.

The other two plant pathogens traditionally included in the genus Corynebacterium, C. fascians (Tilford 1936) Dowson 1942 and C. ilicis (Mandel et al. 1961 [M. Mandel, E. F. Guba, and W. Litsky, Bacteriol. Proc., p. 61, 1961]), have protein patterns in polyacrylamide gels that distinguish them from each other and from the rest of the phytopathogens (Fig. 7). On this basis, we agree with Dye and Kemp (14) that these bacteria are legitimate species.

The bacterial mosaic pathogen clearly belongs in the species $C$. michiganense on the basis of the near identity of its protein bands in polyacrylamide gels with those of other $C$. michiganense strains (Fig. 4 and 5), the presence of diaminobutyric acid in its cell wall (M. Davis, personal communication) (Table 3), and similar $\mathrm{G}+\mathrm{C}$ values (Table 2 ). However, the bacterial mosaic pathogen can be distinguished from the other above-mentioned subspecies of $C$. michiganense by pigmentation and morphology on NBY medium, growth on CNS medium, tetrazolium salt tolerances, overall bacteriocin production, and comparative pathogenicity data. In our opinion, these differences warrant the establishment of a new subspecies of $C$. michiganense. Therefore, we propose that the name of the bacterial mosaic pathogen be Corynebacterium michiganense subsp. tessellarius. A description of this new taxon follows.

Corynebacterium michiganense subsp. tessellarius subsp. nov. (tes.sel.lar.'i.us. L. mas. noun tessellarius a mosaic stone maker). Gram-positive, pleomorphic rods that are nonmotile between 20 and $28^{\circ} \mathrm{C}$ and measure approximately 0.5 by $1.5 \mu \mathrm{m}$. Colonies are circular (diameter, 2 to $4 \mathrm{~mm}$ ), convex, glistening, and butyrous and have entire margins. Optimal growth occurs between 24 and $28^{\circ} \mathrm{C}$; strains grow at $10^{\circ} \mathrm{C}$ but not at $37^{\circ} \mathrm{C}$. All strains produce an apricot orange pigment, the intensity of which varies with the growth medium and the age of the culture. Strains grow on NBY medium. This taxon is distinguished from other corynebacteria on the basis of the $\mathrm{G}+\mathrm{C}$ content $(74 \mathrm{~mol} \%)$ of its DNA, the presence of diaminobutyric acid in its peptidoglycan, and its distinct pattern of protein bands in polyacrylamide gels. It is distinguished from the other subspecies of C. michiganense by colony pigment, colony morphology, ability to grow on the CNS medium and tetrazolium chloride medium (containing either triphenyltetrazolium chloride or iodonitrotetrazolium), and its host specificity (pathogenic to wheat $[T$. aestivum L.], causing foliar lesions in a mosaic 
pattern). The type strain is strain $78181 \quad(=$ ATCC $33566=$ PDDCC 7221). The species description is based on six strains (Table 1) which have different bacteriocin production characteristics, but cannot otherwise be distinguished. Thus, the species description is also the type strain description.

\section{ACKNOWLEDGMENTS}

We thank Les Lane for advice and encouragement, Manley Mandel for performing the $\mathrm{G}+\mathrm{C}$ determinations. Douglas Dye for constructive criticism and comments, and George Morris for the electron micrographs.

\section{REPRINT REQUESTS}

Address reprint requests to: Anne K. Vidaver, Department of Plant Pathology, 406 Plant Sciences Hall, University of Nebraska, Lincoln, NE 68583-0722.

\section{LITERATURE CITED}

1. Ames, G. F.-L. 1974 . Resolution of bacterial proteins by polyacrylamide gel electrophoresis on slabs. J. Biol. Chem. 249:634-644.

2. Bergey, D. H., F. C. Harrison, R. S. Breed, B. W. Hammer, and F. M. Huntoon. 1923. Bergey's manual of determinative bacteriology, 1st ed. The Williams \& Wilkins Co., Baltimore.

3. Bousfield, I. J. 1972. A taxonomic study of some coryneform bacteria. J. Gen. Microbiol. 71:441-455.

4. Buchanan, R. E., and N. E. Gibbons (ed.). 1974. Bergey's manual of determinative bacteriology, 8th ed. The Williams \& Wilkins Co., Baltimore.

5. Burkholder, W. H. 1948. Genus I. Corynebacterium Lehmann and Neumann, p. 381-408. In R. S. Breed, E. G. D. Murray, and A. P. Hitchens (ed.), Bergey's manual of determinative bacteriology, 6th ed. The Williams \& Wilkins Co., Baltimore.

5a. Carlson, R. R., and A. K. Vidaver. 1982. Bacterial mosaic, a new corynebacterial disease of wheat. Plant Dis. 66:76-79.

6. Clark, F. E. 1952. The generic classification of the soil corynebacteria. Int. Bull. Bacteriol. Nomencl. Taxon. 2:45-56.

7. Cohn, F. 1872. Untersuchungen über Bakterien. Beitr. Biol. Pflanz. 1:127-224.

8. Collins, M. D., M. Goodfellow, and D. E. Minnikin. 1979. Isoprenoid quinones in the classification of coryneform and related bacteria. J. Gen. Microbiol. 110:127-136.

9. Collins, M. D., M. Goodfellow, and D. E. Minnikin. 1980. Fatty acid, isoprenoid quinone and polar lipid composition in the classification of Curtobacterium and related taxa. J. Gen. Microbiol. 118:29-37.

10. Collins, M. D., and D. Jones. 1980. Lipids in the classification and identification of coryneform bacteria containing peptidoglycans based on 2,4-diaminobutyric acid. J. Appl. Bacteriol. 48:459-470.

11. Conn, H. J., and I. Dimick. 1947. Soil bacteria similar in morphology to Mycobacterium and Corynebacterium. J. Bacteriol. 54:291-303.

12. Da Silva, G. A. N., and J. G. Holt. 1965. Numerical taxonomy of certain coryneform bacteria. J. Bacteriol. 90:921-927.

13. Dowson, W. J. 1942. On the generic name of the grampositive bacterial plant pathogens. Trans. Br. Mycol. Soc. 25:311-314

14. Dye, D. W., and W. J. Kemp. 1977. A taxonomic study of plant pathogenic Corynebacterium species. N. Z. J. Agric. Res. 20:563-582.

15. Gross, D. C., and J. E. Devay. 1977. Population dynamics and pathogenesis of Pseudomonas syringae in maize and cowpea in relation to in vitro production of syringomycin. Phytopathology 67:475-483.
16. Gross, D. C., and A. K. Vidaver. 1979. A selective medium for isolation of Corynebacterium nebraskense from soil and plant parts. Phytopathology 69:82-87.

17. Gross, D. C., and A. K. Vidaver. 1979. Bacteriocins of phytopathogenic Corynebacterium species. Can. J. Microbiol. 25:367-374.

18. Gross, D. C., A. K. Vidaver, and M. B. Keralis. 1979. Indigenous plasmids from phytopathogenic Corynebacterium species. J. Gen. Microbiol. 115:479-489.

19. Hedges, F. 1922. A bacterial wilt of the bean caused by Bacterium flaccumfaciens nov. sp. Science 55:433-434.

20. Hutchinson, C. M. 1917. A bacterial disease of wheat in the Punjab. Mem. Dep. Agric. India Bacteriol. Ser. 1:169_ 175 .

21. Jensen, H. L. 1934. Studies on saprophytic mycobacteria and corynebacteria. Proc. Linnean Soc. N. S .W. 59:1961.

22. Jones, D. 1975. A numerical taxonomy study of coryneform and related bacteria. J. Gen. Microbiol. 87:52-96.

23. Keddie, R. M. 1978. What do we mean by coryneform bacteria?, p. 1-12. In I. J. Bousfield and A. G. Calley (ed.), Coryneform bacteria. Academic Press, Inc., London.

24. Keddie, R. M., and G. L. Cure. 1978. Cell wall composition of coryneform bacteria, p. 47-83. In I. J. Bousfield and A. G. Calley (ed.), Coryneform bacteria. Academic Press, Inc., London.

25. Kelman, A. 1954. The relationship of pathogenicity in Pseudomonas solanacearum to colony appearance on a tetrazolium medium. Phytopathology 44:693-695.

26. Kersters, K., and J. De Ley. 1975. Identification and grouping of bacteria by numerical analysis of their electrophoretic protein patterns. J. Gen. Microbiol. 87:333-342.

27. Keyworth, W. G., J. S. Howell, and W. J. Dowson. 1956. Corynebacterium betae (sp. nov.) the causal organism of silvering disease of red beet. Plant Pathol. 5:88-90.

28. Kruse, W. 1896. Systematik der Streptothricheen und Bakterien, p. 185-526. In C. Flügge (ed.), Die Mikroorganismen, 3rd ed., vol. 2. F. C. W. Vogel, Leipzig.

29. Laemmli, U. K. 1970. Cleavage of structural proteins during the assembly of the head of bacteriophage $\mathrm{T} 4$. Nature (London) 227:680-685.

30. Lapage, S. P., P. H. A. Sneath, E. F. Lessel, V. B. D. Skerman, H. P. R. Seeliger, and W. A. Clark (ed.). 1975. International code of nomenclature of bacteria. 1975 revision. American Society for Microbiology, Washington, D.C.

31. Larsen, S. A., S. T. Bickham, T. M. Buchanan, and W. L. Jones. 1971. Polyacrylamide gel electrophoresis of Corynebacterium diphtheriae: a possible epidemiological aid. Appl. Microbiol. 22:885-890.

32. Lehmann, K. B., and R. O. Neumann. 1896. Atlas and Grundriss der Bakteriologie und Lehrbuch der speziellen bakteriologischen Diagnostik, 1st ed. J. F. Lehmann, München.

33. Masuo, E., and T. Nakagawa. 1969. Numerical classification of bacteria. II. Computer analysis of coryneform bacteria. (2) Comparison of group formations obtained on two different methods of scoring data. Agric. Biol. Chem. 33:1124-1133.

34. McCulloch, L. 1925. Aplanobacter insidiosum n. sp. the cause of an alfalfa disease. Phytopathology 15:496-497.

35. Nelson, G. A., and G. Semeniuk. 1964. An antagonistic variant of Corynebacterium insidiosum and some properties of the inhibitor. Phytopathology 54:330-335.

36. Perkins, H. R., and C. S. Cummins. 1964. Chemical structure of bacterial cell walls. Nature (London) 201:11051107.

37. Robinson, K. 1966. An examination of Corynebacterium spp. by gel electrophoresis. J. Appl. Bacteriol. 29:179184 .

38. Saaltink, G. J., and H. P. Maas Geesteranus. 1969. A new disease in tulip caused by Corynebacterium oortii nov. spec. Neth. J. Plant Pathol. 75:123-128. 
39. Scharif, G. 1961. Corynebacterium iranicum sp. nov. on wheat (Triticum vulgare L.) in Iran, and a comparative study of it with $C$. tritici and $C$. rathayi. Entomol. Phytopathol. Appl. 19:1-24.

40. Schroeter, J. 1872. Ueber einige durch Bakterien gebildete Pigmente, p. 109-126. In F. Cohn (1875). Beitr. Biol. Pflanz., J. U. Kern's Verlag, Breslau.

41. Schuster, M. L., B. Hoff, M. Mandel, and I. Lazar. 1973. Leaf freckles and wilt, a new corn disease, p. 176-191. In Proceedings of the 27th Annual Corn and Sorghum Research Conference. American Seed Trade Association, Washington, D.C.

42. Schuster, M. L., A. K. Vidaver, and M. Mandel. 1968. A purple-pigment-producing bean wilt bacterium, Corynebacterium flaccumfaciens var. violaceum, n. var. Can. J. Microbiol. 14:423-427.

43. Skaptason, J. B., and W. H. Burkholder. 1942. Classification and nomenclature of the pathogen causing ring rot of potatoes. Phytopathology 32:439-441.

44. Skerman, V. B. D., V. McGowan, and P. H. A. Sneath (ed.). 1980. Approved lists of bacterial names. Int. J. Syst. Bacteriol. 30:225-420.

45. Smith, E. F. 1910. A new tomato disease of economic importance. Science 31:794-796.

46. Smith, E. F. 1913. A new type of bacterial disease. Science 38:926.

47. Spieckermann, A., and P. Kotthoff. 1914. Untersuchungen über die Kartoffelpflanze und ihre Krankheiten. Landwirtsch. Jahrb. 46:659-732.

48. Stackebrandt, E., B. J. Lewis, and C. R. Woese. 1980. The phylogenetic structure of the coryneform group of bacteria. Zentralbl. Bakteriol. Parasitenkd. Infektionskr. Hyg. Abt. 1 Orig. Reihe C 1:137-149.

49. Starr, M. P., M. Mandel, and N. Murata. 1975. The phytopathogenic coryneform bacteria in the light of DNA base composition and DNA-DNA segmental homology. J. Gen. Appl. Microbiol. 21:13-26.

50. Starr, M. P., and P. P. Pirone. 1942. Phytomonas poinsettiae n. sp., the cause of bacterial disease of poinsettia. Phytopathology 32:1076-1081.

51. Studier, F. W. 1973. Analysis of bacteriophage T7 early RNAs and proteins on slab gels. J. Mol. Biol. 79:237-248.

52. Tilford, P. E. 1936. Fasciation of sweet pea caused by Phytomonas fascians n. sp. J. Agric. Res. 53:383-394.

53. Van Etten, J. L., and S. N. Freer. 1978. Polyadenylatecontaining RNA in dormant and germinating sporangiospores of Rhizopus stolonifer. Exp. Mycol. 2:301-312.

54. Van Etten, J. L., S. N. Freer, and B. K. McCune. 1979. Presence of a major (storage?) protein in dormant spores of Botryodiplodia theobromae. J. Bacteriol. 138:650-652.

55. Vidaver, A. K. 1967. Synthetic and complex media for the rapid detection of fluorescence of phytopathogenic pseudomonads: effect of the carbon source. Appl. Microbiol. 15:1523-1524.

56. Vidaver, A. K., and M. Mandel. 1974. Corynebacterium nebraskense, a new, orange-pigmented phytopathogenic species. Int. J. Syst. Bacteriol. 24:482-485.

57. Yamada, K., and K. Komagata. 1972. Taxonomic studies on coryneform bacteria. V. Classification of coryneform bacteria. J. Gen. Appl. Microbiol. 18:417-431.

58. Yamada, Y., G. Inouye, Y. Tahara, and K. Kondo. 1976. The menaquinone system in the classification of coryneform and nocardioform bacteria and related organisms. J. Gen. Appl. Microbiol. 22:203-214.

59. Zagallo, A. C., and C. H. Wang. 1967. Comparative carbohydrate catabolism in corynebacteria. J. Gen. Microbiol. 47:347-357. 